\title{
9
}

\section{PATERNALISM AND DUTIES TO SELF}

\author{
Michael Cholbi
}

Ordinary moral thought, and much of contemporary moral philosophy, tend to assume a social conception of morality. On this conception, our moral duties are exclusively other-regarding, that is, all our moral duties are ultimately justified by appeal to morally salient facts about other people. Proponents of this social conception of morality disagree about the source and extent of our moral duties. Nevertheless, that morality is a social tool, a set of principles or practices concerned with how we treat one another, is the guiding assumption of this conception of morality.

No doubt a significant portion of morality is social in this way. Historically, however, many moral thinkers have maintained that in addition to our other-regarding duties, we also have selfregarding duties or duties to self. We shall have occasion later to state more precisely what duties to self are, but at a rough level, duties to self are duties the performance or fulfillment of which by individual $\mathrm{S}$ is owed to $\mathrm{S}$. When an individual fails to fulfill a duty to self, it is she, and not other people, who is thereby wronged.

The dominance of the social conception of morality has meant that contemporary moral philosophy pays scant attention to duties to self, and what attention it has paid has largely been skeptical of such duties. In my estimation, duties to self have been inadequately analyzed by philosophers, and as a result, prematurely dismissed. Suppose instead that there are duties to self and that the social conception of morality is mistaken. This supposition would have many implications, but the implications would be of particular interest to philosophers interested in the moral justification of paternalism. The debate about paternalism primarily concerns whether it can be morally justified to intercede, without their consent or authorization, in the choices or actions of rationally competent individuals so as to make those individuals better off in some way. Those sympathetic to paternalism may see duties to self as another avenue through which to intercede in individuals' choices or action for their benefit, namely, so as to enable them to fulfill such duties.

The purpose of this chapter is to sift through the ramifications of duties to self for the moral justification of paternalism. In some respects, duties to self do not appear to introduce any new considerations into these debates. However, I shall argue that the distinctive nature of the goods associated with duties to self, namely, that the values of these goods to an individual turn crucially on that individual's playing a key role in their realization, entails that we have reasons to resent paternalism directed at aiding our fulfillment of these duties, reasons that we do not have for resenting paternalism directed at realizing goods typically associated with our welfare. 
But of course these conclusions are of merely theoretical interest if, as many philosophers have maintained, there simply are no duties to self. Hence our first task is to clarify and rehabilitate duties to self. The first two sections thus offer a model of duties to self, based on Kant's account of such duties, and answer common objections to the existence of these duties.

\section{Clarifying duties to self: the Kantian model}

The preeminence of the social conception of morality may make duties to self seem exotic or obscure. Let us then first clarify the nature of these duties, making reference to Kant's account of duties to self, arguably the most systematic and fully developed account of such duties. ${ }^{1}$

The "first principle" of duties to self, according to Kant, is to "live in conformity with nature, '... that is, to preserve yourself in the perfection of your nature; the second in the saying, 'make yourself more perfect than mere nature has made you'" (Kant 1996: 175/6:419). As Kant saw it, fundamental to our nature is the fact that we are practically rational agents, capable of choosing our goals and the means to achieving those goals. Our capacity for rational agency is thus the source of a distinct class of self-regarding moral duties. The various duties to self, for Kant, therefore correspond to various ways in which that capacity is to be respected and cultivated.

Kant divides duties to self into three categories. (His motivations for this division need not concern us here.) The first category are duties we owe ourselves due to our "animal," i.e., physi$\mathrm{cal}$, nature. The most fundamental of these duties is the duty of bodily self-preservation. This precludes our killing ourselves as well as our intentionally disabling or incapacitating our bodies (1996: 176-177/6:422). The other duties in this category are not to imbibe in food or drink in ways that impede our powers of "skill and deliberation" (1996: 180/6:427). What unites the duties we owe ourselves as animal beings is that in violating them, we inhibit our capacity to exercise, and hence fail to respect, our rational agency.

A second category of duties to self concern our "moral" nature. These include a duty to avoid "avarice," the condition in which one does not make use of one's resources to meet one's basic needs, as well as a duty not to make oneself servile to others. (Selling ourselves into slavery or acquiring crushing debts are examples of the servility Kant condemns.) Whether through stubbornly hoarding one's resources (avarice) or through subjugating one's will to another's (servility), violations of these duties inhibit our capacity to pursue our chosen ends and so show a lack of respect for our rational capacities.

The final Kantian category of duties to self concern the pursuit of our "natural perfection." We have, according to Kant, duties to cultivate our mental and physical talents so as to enhance our ability to pursue our chosen goals. In so doing, we respect our rational agency by rendering it more efficacious. Kant terms this an "imperfect" duty, meaning that we are not required to develop all our talents to the greatest degree. Rather, this duty allows our choice of which talents to develop to be guided by our tastes and interests.

Note that in speaking of duties to self, Kant (and other proponents of such duties) assume that at least some of our duties are "directed," that is, their performance is owed to specifiable individuals (May 2015). This assumption is not one shared by all moral theorists. Adherents of some versions of impersonal consequentialism, for example, maintain that, at root, all our moral duties are duties to bring about particular states of affairs, namely, to perform the act that results in the best overall outcome. According to such theories, to speak of duties being directed or owed to particular individuals is somewhat misleading, for even if (say) a particular individual stands to benefit from the fulfillment of our duty to bring about the best overall outcome, the duty is not fundamentally owed to her. According to these theories, if we have a moral duty to provide disaster relief, this is because doing so will result in the best overall outcome, not because 
it is owed to the particular beneficiaries of that relief; if we have a moral duty to be beneficent toward our siblings, this is because doing so will result in the best overall outcome, not because such beneficence is owed to our siblings; etc. That at least some of our duties are directed is far from a trivial assumption, but it raises issues in moral theory too large to be addressed here. There are also other controversial aspects of Kant's particular account of duties to self that we have not pursued in detail here, ${ }^{2}$ and a fuller defense of duties to self would involve comparing the strengths and weaknesses of Kant's account to others. Nevertheless, Kant's account is instructive, highlighting three crucial features of duties to self.

First, his account highlights the properties of duties to self that distinguish them from duties to others. All duties are duties of selves, i.e., duties that call upon individuals to act in prescribed ways. What licenses classifying a duty as a duty to self? A useful method for capturing the essence of duties to self is to distinguish between the subject of a duty, that individual required to fulfill a given duty, and the object of a duty, that individual to whom fulfillment of a duty is owed (Hills 2003: 132; Timmermann 2006: 506). An other-regarding duty is such that the subject and the object of the duty necessarily diverge. If $\mathrm{S}$ is obligated not to harm $\mathrm{T}$, then $\mathrm{S}$ is the duty's subject, $\mathrm{T}$ its object. If $\mathrm{S}$ wrongfully harms $\mathrm{T}$, then $\mathrm{T}$ is wronged by $\mathrm{S}$. In contrast, if $\mathrm{S}$ has duties to self (duties, as Kant believed, to preserve our bodily powers, develop our talents, forego servility, etc.), then when $S$ fails in these duties, $S$ herself is wronged by these failures. Note that a duty to self is therefore something more than a duty to treat oneself in a particular way. For instance, suppose you promise your fiancée that you will get a haircut before your wedding ceremony. The duty requires you to treat yourself in a particular way, but it is a duty whose object is the person to whom you made the promise, your fiancée. This duty is actually other-regarding, but because it demands a certain treatment of yourself, some call these duties concerning oneself or indirect duties to self.

Duties to self thus have a distinct object. But Kant's account also highlights that duties to self have a distinct subject too. If $\mathrm{S}$ has a particular duty to herself, then no one but $\mathrm{S}$ has that duty (though of course others are subject to the same duties with regard to themselves as $S$ is with regard to herself). In Kant's terms, our duties to preserve our bodies, etc., are, by their very nature, duties that are not morally incumbent on others. A duty to self, therefore, is a duty in which the subject and object converge, that is, a duty to self is one whose fulfillment is owed to the very same person with the duty to fulfill it.

Third and finally, note that on Kant's account of duties to self, these are not welfare-based duties, i.e., they are not duties grounded in requirements to promote one's own welfare. The point of Kant's duties to self is not that by fulfilling them our lives will go better or be happier, in any ordinary sense. Rather, their point is to show respect for ourselves as rational agents. The person who fulfills her self-regarding duties maintains a kind of "moral health," a condition wherein her capacities to choose her goals with rational lucidity and to follow the most suitable plans for realizing those goals are unimpaired and not harnessed to the rational wills of others. But the maintenance of our moral health not only does not require us to promote our own welfare - in fact, it may demand that we forego opportunities to promote our own welfare. No doubt individuals can find themselves in situations wherein their own goals are promoted by ending their lives prematurely via suicide or by selling themselves into slavery. Kant's duties to self morally preclude such actions, despite the likelihood that they can contribute to individual welfare.

\section{Answering skeptics about duties to self}

Armed with Kant's account of duties to self, we are now in a position to address skeptics about duties to self, especially adherents to the social conceptions of morality. 
Perhaps the boldest argument for rejecting duties to self is to assert that morality conceptually precludes self-regarding considerations altogether. Stephen Finlay (2008: 140-142) claims that "only considerations arising from the interests of others" belong to the "ordinary" understanding of morality, and given the authority of this ordinary understanding, we should reject duties to self. Morality is "purely and essentially other-regarding," Finlay concludes. No doubt Finlay is correct that self-regarding considerations have a marginal role in ordinary moral understanding. However, the fact that moral understandings are historically contingent should give us pause. As Peter Singer (2011) has observed, the last several centuries have witnessed a slow but steady growth in our "moral circle," as the scope of our moral concern has expanded to include animals, distant strangers, future generations, etc. The decline of philosophical and popular recognition of duties to self - a shrinkage in our moral circle - is therefore puzzling, even ironic: Why should our moral circle not also include our selves? At the very least, given that duties to self were part of ordinary moral understanding as recently as Kant's time, we ought not conclude that current moral understandings, with their apparent exclusion of duties to self, reflect the correct concept of morality as opposed to being one possibly mistaken conception of morality.

Finlay offers a second reason for skepticism about duties to self: if there were such duties, Finlay argues, then morality would condemn actions in which a person engages in extensive sacrifice of her own interests, particularly in order to protect or advance the interests of others. But because morality does not condemn such actions, and in fact finds them praiseworthy, there must not be duties to self (2008: 140). Here we see Finlay incorrectly interpreting duties to self as requiring that individuals promote their own welfare, so that large-scale sacrifices of one's own welfare are morally objectionable. However, we saw in Kant's account of duties to self that such duties need not be oriented around the promotion of one's own welfare. Hence, we need not suppose either that duties to self include a duty to promote one's own welfare or that moral theories acknowledging duties to self oppose acts of extensive self-sacrifice. Indeed, it is a strength of Kant's account of duties to self that it does not ground these duties in considerations of welfare, and as a result, can affirm the intuition that morality permits, even lauds, foregoing one's own welfare.

A third skeptical argument is that it is always possible and morally permissible for the object of a duty to release its subject from its performance; but no one can release herself from a duty; thus, there can be no duties in which the subject and object are the same individual, i.e., no duties to self. This argument is vulnerable at a number of points. For one, this argument is most often pressed in the context of promissory obligations (Singer 1959; Hills 2003: 132-134). What meaning can be given, skeptics about self-regarding duties ask, to a duty to keep a promise one made oneself if one has unfettered liberty to waive the duty by releasing oneself from it? Note though that Kant does not propose that there can be duties stemming from promises to oneself, and there does not seem to be any particular reason to suppose that promises can generate duties to self unless one makes the unlikely assumption that each of our other-regarding duties must have a parallel self-regarding duty.

Moreover, even if this "releaseability" argument spells doom for self-regarding promissory duties, it may not extrapolate to other self-regarding duties. In fact, releaseability is not a paradigmatic feature of duties to self. Kant certainly did not hold that we could simply opt out of our duties to preserve our lives, abjure servility, etc. ${ }^{3}$ Indeed, our ability to release others from the duties they owe us seems to imply that we have duties to self from which we cannot release ourselves. We are morally permitted to waive the duties others owe us, as when, by giving informed consent to a medical treatment, we waive our right that others not interfere with our bodies. But this moral power to alienate our interpersonal rights seems to require that there be some inalienable right in us, a right resting on some value we have as rational agents (Velleman 1999: 611-612). 
Michael Cholbi

Advocates of duties to self should therefore not take the fact that we cannot release ourselves from them as an embarrassment or an anomaly in need of explanation. Rather, their non-releaseability is a consequence of the nature of the value on which such duties logically depend.

A final related worry about duties to self is that it appears difficult to make sense of accountability with respect to such duties. Ordinarily, moral duties carry the implication that those objects wronged by their violation can and should hold the subjects accountable for these violations, by adopting certain attitudes toward them (blame, resentment, etc.) or by treating them in particular ways (punishment, for instance). Marcus Singer (1959) hints that we cannot coherently hold ourselves accountable for violations of self-regarding duties. I do not see that this is so, however. We can and do feel guilt at entering into servile relations with others in order to promote our goals; we can and do feel resentment at the slothfulness that leads us to neglect our talents or to permit our bodies to deteriorate; and we can and do "punish" ourselves for violations of duties to self by predicating future rewards on their fulfillment (Cholbi 2015). Granted, the network of normative concepts we use to describe our accountability for self-regarding duties is likely to differ from the network used to describe our accountability for other-regarding duties. Our vocabulary for the latter is more likely to reference harms, rights, etc., whereas the vocabulary for the former is more likely to reference disappointment, regret, or self-respect. But these conceptual differences only suggest that self-regarding duties have a different normative basis from other-regarding duties, not that they have no basis whatsoever.

Thus, none of these considerations provide compelling reasons to reject duties to self. Indeed, these skeptical arguments can be justly accused of not taking seriously the prospect of duties to self as a distinct deontic category. All proceed on the assumption that duties to self, to earn their philosophical credibility, must be modeled on duties to others, and because (allegedly) they cannot be so modeled, they must be rejected. The replies provided to these arguments show that this assumption largely begs the question against duties to self.

\section{Paternalism and the fulfillment of duties to self}

Assuming then that there are duties to self as Kant envisioned them, let us now turn to our central aim, namely, exploring the implications that self-regarding duties have for the moral justification of paternalism. Two caveats are in order before embarking on this exploration.

No doubt paternalism could be motivated by the desire that others fulfill their duties to themselves, and efforts to lead others to choose or act so as to fulfill these duties would count as paternalistic inasmuch as they are motivated not by the interests, rights, etc., of paternalists or of the community at large but by the aim of leading others to do something thought good for themselves, namely, fulfilling their duties to self. However, we must not overestimate the efficacy of paternalistic measures in leading others to fulfill their self-regarding duties. For as Kant pointed out, duties to self are "duties of virtue" rather than "duties of right" (1996: 31/6:239). We can be moved to fulfill duties of right via "external" compulsion or coercion because their requirements are essentially behavioral. For instance, the threat of punishment may convince someone to refrain from stealing. Her behavior thus fulfills her duty to respect others' property, and she need not act from any specific motive in order for that duty to be fulfilled. Duties of virtue, in contrast, demand that we behave in particular ways on the basis of certain reasons, or in Kant's terms, that we adopt a particular “end." Our duties to self, according to Kant, belong in this second category. Our duty of self-preservation, for example, is not fulfilled simply by keeping ourselves alive. It is fulfilled when we keep ourselves alive because keeping ourselves alive is among our ends. Because duties to self require that we act on the basis of particular reasons or ends, their fulfillment cannot be coerced or compelled by "external" means. The fulfillment 
of our duties to self must instead be a matter of "free self-constraint" (Kant 1996: 147/6:382). Note that this does not mean that we cannot be compelled to behave as if we have such ends. A person planning to end her life, for instance, could be compelled to preserve herself if someone threatened to harm one of her loved ones if she proceeded with that plan. But in such a case, she will have conformed her behavior to the duty of self-preservation but will not have fulfilled that duty, since her end was not self-preservation (or respect for her own rational agency more generally) but protecting a loved one. This fact implies that paternalistic efforts aimed at leading individuals to honor their duties to self cannot succeed in a strict sense. We cannot compel, coerce, etc., others to keep themselves alive, develop their talents, and so on, for the sake of their self-regarding duties. But paternalists can hope to influence individuals so as to behave in accordance with these duties and, over the long run, to shape their character in ways conducive to their fulfillment. Take Kant's duty to refrain from "stupefying" ourselves with food or drink. Paternalistic measures such as alcohol taxes, etc., cannot compel people to refrain from excessive drinking out of respect for their own rational agency. But they could encourage moderation, reduce temptation, etc., so as to engender or habituate such respect. ${ }^{4}$

The second caveat concerns the kind of paternalism that duties to self make possible. Paternalism can be good for its target in one of two ways. Welfare paternalism aims to improve its targets' well-being, happiness, life-satisfaction, etc. Moral paternalism aims to improve its targets' moral conduct or character. Duties to self do not, as we have observed, acquire their rationale from welfare considerations; the Kantian duties to preserve our bodies, avoid servility, and the like are duties that bind us irrespective of how honoring these duties may contribute to our own welfare. Hence, there cannot be welfare-based reasons to justify paternalistic intercessions based on a concern for targets' ability to fulfill their self-regarding duties. Such intercessions could only be justified as species of moral paternalism. This does not preclude paternalism that uses the promotion of welfare as a means of facilitating its targets' fulfilling their self-regarding duties. Paternalistic anti-poverty measures, for instance, could increase their targets' welfare so that the targets will find income-producing activities that involve servility (jobs requiring a person to forego basic liberties, for instance) less appealing.

These two considerations bring into clearer view the sort of paternalism that duties to self might license: measures that facilitate, encourage, or reward individuals coming to have their own rational agency as one of their basic ends by facilitating, encouraging, or rewarding selfregarding choices that in turn foster the fulfillment of duties to self. The question at hand is whether such measures are morally justified.

\section{A dialectical cul-de-sac?}

The prospect that duties to self invite suspect forms of moral paternalism has sometimes been invoked as a reason to reject duties to self. Some have reasoned that if there were duties to self, communities might well feel compelled to enforce those duties, which would in effect treat individuals as children needing protection not only from others, but also from themselves (Baier 1958: 250; Denis 2001: 4-5). Suppose, for example, that among our duties to self is a duty of self-preservation. A community acknowledging such a duty could take measures that seek to prevent individuals from engaging in suicide. Some of these measures would be morally benign (Cholbi 2011: 116-117), but others would involve significant intrusions into individuals' personal spheres of action (e.g., monitoring social media for evidence of suicidal thinking) or liberty (compelling suicidal individuals to take psychotropic drugs, undergo mandatory psychotherapy, or be involuntarily institutionalized). If such measures are the price of acknowledging duties to self, some antipaternalists believe, then that is too great a price to bear. 
However, this antipaternalist reasoning moves too quickly. For one, as we have noted, paternalistic measures cannot compel the fulfillment of duties to self. At most, paternalistic measures can compel the behaviors associated with duties to self (keeping oneself alive, say) in the hopes of inculcating self-regarding virtues. But here antipaternalists may argue that irrespective of whether paternalistic measures can compel the fulfillment of self-regarding duties, paternalistic efforts guided by the aim of helping individuals to fulfill such duties are nevertheless morally prohibited. For if, as Mill (1859) asserted, the only basis for interfering with a person's choices or actions without her consent is "self-protection" - that the individual's own good, "physical or moral," is "not a sufficient warrant" for such interference - then paternalism in order to inculcate self-regarding moral character is ruled out. Indeed, whatever the case for moral paternalism in general, the case for this form of moral paternalism appears especially weak. The inculcation of other-regarding virtues (generosity, sympathy, a sense of justice, etc.) will shape how the members of a community treat one another. But the only individual whose fate is at stake in the inculcation of self-regarding virtues, on the other hand, is the individual. If there is anything in which other people, and the community at large, do not have a stake, it is whether an individual develops the virtues that will enable her to preserve herself, forego avarice, develop her talents needed to advance her own ends, and so on.

Here those more sympathetic to the paternalistic cause may concede that communities do not have a direct interest in whether their members fulfill their self-regarding duties but nevertheless have morally justifiable grounds for paternalism in this regard. Community members ought to care for one another; to care for one another is to desire what is good for others for their own sake (Darwall 2002); the development of the self-regarding virtues needed to fulfill one's duties to self is good for a person for her own sake; so community members ought to take measures to inculcate these virtues in one another, via paternalistic measures if need be; hence, morally paternalistic measures aimed at the inculcation of self-regarding virtues ought to be undertaken. If sound, such an argument would lend support to including the inculcation of the self-regarding virtues as one of the aims of interpersonal conduct and of social policy.

But again, opponents of paternalism may concede that we have good reason to consent to acts and policies that inculcate the self-regarding virtues. It still does not follow, they may argue, that we have good reason to endorse paternalism in this guise. Paternalism, after all, is non-consensual intercession in another's choice or action for their own good. That we ought to consent to others' aid in inculcating self-regarding virtues in us does not obviate the force of this antipaternalist complaint.

\section{Historical and ahistorical goods}

To this point, it may seem that duties to self do not shift familiar debates about the moral justification of paternalism so much as rehash them: given that there are self-regarding duties, they offer a new avenue for moral paternalism. But the considerations offered for and against such paternalism are not fundamentally different from those that drive extant disagreements about paternalism. Advocates of using paternalistic measures cite their potential to inculcate self-regarding virtues that facilitate individuals' fulfilling their duties to self, to their presumed "moral" benefit. Conversely, antipaternalists invoke their cherished thesis that intercessions in others' choices and actions without their consent must be governed solely by considerations about how those choices and actions affect others - and duties to self, as we have seen, are not the concerns of others.

I shall now argue that considerations regarding how the value of goods can be sensitive to how they are realized offer a way out of this dialectical cul-de-sac, and as a result, we have reason 
to oppose paternalism aimed at inculcating self-regarding virtues and the fulfillment of duties to self.

With respect to some goods, it is often of little importance to us how we come to enjoy them. Such is the case, I propose, with many of the goods commonly assumed to contribute to welfare. Take, for instance, the value of relief from pain. Its value to us does not seem to hinge on exactly how pain relief comes about (whether simply from its abating, via the administration of drugs, removal of environmental conditions contributing to the pain, etc.). What matters is that we enjoy freedom from pain, regardless of precisely how that freedom comes about. Such claims should not be exaggerated. It may matter very much morally how our pain relief is attained. We would be justifiably worried to learn that our pain relief came at the expense of causing pain to someone else, for instance. But just insofar as pain relief is good for us, its goodness is ahistorical, independent of how it is realized. So too, I propose, for many other goods that contribute to our welfare. The value of experiencing natural or artistic beauty, for example, does not seem to hinge on how we come into a position to enjoy these goods.

Other goods, however, have a historical quality, such that their value turns in part on how those goods are realized. Some goods, particularly those predicated on one's relationships with others, derive their value from norms expressing and governing our attitudes. Hence, the value of a good whose history contains choices or events at odds with those norms is thereby called into question (Anderson 1993: 38-43; Scanlon 2008: 128-141). For instance, there are aspects of the good of friendship that do not seem to depend on how the friendship is established or maintained. One can find value in a friend's companionship regardless of the friendship's history, for example. Nevertheless, the value of a friendship can turn on its history. Friendships that result from sharing a workplace with someone are not thereby diminished in value, but it is hard to fathom that learning that one became friends with someone only after she was hired by one of your rivals to surveil you would not imperil the value one attributes to that friendship. It would be reasonable to question whether a friendship with such origins can embody the norms of mutual respect definitive of friendship and whether the friend has the attitudes characteristic of genuine friendship.

But just as the histories of relationships with others can influence the value those relationships have for us, so too can the history of how we relate to ourselves influence the value of the goods associated with that relationship. In other words, many of the goods associated with our relationships to ourselves have a noticeably historical character. Gwen Bradford has recently homed in on one important class of such goods, achievements. Under Bradford's characterization, achievements are those products of our efforts that are difficult to attain but are attained nevertheless via our competently causing them $(2015: 20)$. An achievement is therefore a state that can be distinctly attributed to our efforts and more specifically, Bradford argues, to the exercise of our volitional powers. When (say) a person completes her first triathlon, this result was not easy to achieve, was achieved through her competent efforts (sustained training, etc.), and required steadfastness. Achievements give our lives meaning and worth, then, in part because of the history of their realizations. Suppose that, against all probability, a person is able to complete the triathlon easily, through sheer luck and modest effort. Its value qua achievement would thereby be reduced accordingly.

That achievements matter to us shows that the value of some goods hinges on the history of how they are realized, and in particular, how our own choices and efforts contribute to their realization. For some goods, it is not good (enough) that $\mathrm{P}$ - we must make it the case that $\mathrm{P}$ in order for $\mathrm{P}$ to matter to us wholeheartedly. The desire for such goods to be realized through our own wills reflects an implicit normative understanding of our relationship to these goods and to our selves. That we instantiate these goods does not exhaust their value to us. Their value to us 


\section{Michael Cholbi}

stems in part from our standing in an authentic relationship to them - that they in some manner are a reflection of us. As I suffer from a toothache, it matters little to me whether relief comes from my efforts or not - it is of little normative import whether the relief reflects positively on my character, will, etc. In contrast, as I prepare to compete in my first triathlon, it matters to me that I (and others) can rightfully acknowledge that I am able (thanks to my preparation, dedication, mental resilience, etc.) to complete all three of its component events.

We noted in Section 1 that duties to self are both owed to our selves but also owed by our selves. As we noted, duties to self are, in Kant's scheme in particular, duties of virtue, and so cannot be fulfilled by others, strictly speaking. This is the metaphysical explanation of why duties to self cannot be fulfilled by others. But even if this were not the case and others could fulfill these duties, there would be something ethically amiss about their doing so. For duties to self, I propose, rest on what I have been calling historical values. What matters to us about the fulfillment of duties to self - why it is apt for us to feel proud of how we care for our bodies, manage our resources so as to further our ends, develop our talents, retain relations with others that are independent rather than servile, etc. - is that we bring about their fulfillment. Indeed, the fulfillment of duties to self only seems to reflect positively upon us, and upon our respect for ourselves as rational agents owed authority over our choices, if their fulfillment is attributable to us.

Again, others cannot fulfill our self-regarding duties. However, insofar as we are the object of these duties - those to whom the duty is owed - we are not indifferent to who their subject is. That duties to self rest on historical goods thus implies that the division of labor between ourselves and others, as far as whose volitions are responsible for their fulfillment is concerned, should tilt heavily in the direction of the former. The more their fulfillment can be attributed to the choices and efforts of others, the less significant their fulfillment is to us. Resentment directed at paternalism aimed at the inculcation of the self-regarding virtues is thus understandable. For others to make the inculcation of one's self-regarding virtues their business is to undermine the conditions under which their fulfillment is normatively significant to the person to whom they are owed. Paternalists motivated by the aim of inculcating the self-regarding virtues in others are interceding in the most intimate relationship we can have: the relationship between our selves as agents and as patients, the relationship most central to our self-governance (Cholbi 2014).

Achievements, we noted above, involve historical goods. Often, the fulfillment of duties to self will be an achievement. After all, the laziness that precludes our developing our talents, the indiscipline that leads us to neglect our bodily health, etc., can be difficult to overcome. Some agents will be advantaged in this regard, however, endowed with the self-regarding virtues to an unusually high degree. But even they, I propose, have reason to desire that their self-regarding duties be fulfilled through their exercise of these virtues rather than from well-meaning paternalists. Of course, at the other end of spectrum, sometimes others' assistance can help us develop our self-regarding virtues. But consenting to such assistance is evidence of the presence of the very powers associated with these virtues. Indeed, in knowing when others can assist us in developing these virtues, we exhibit the virtues associated with respect for ourselves: genuine knowledge of our own traits and aptitudes is itself a developed talent, a way of acquiring resources needed to achieve our ends and a way of being benefitted by others without courting servility to them. Hence, we ought not resent the assistance we accept from others in helping us meet our self-regarding duties in the way that we ought to resent unsolicited, i.e., paternalistic, assistance. After all, when we fulfill our duties thanks to the welcome assistance of others, their fulfillment is nevertheless ultimately traceable to the exercise of our volitional capacities.

The metaphysical identity of deontic subject and object in the case of duties to self thus renders their fulfillment valuable in a way that speaks against paternalistic efforts to inculcate 
the self-regarding virtues that facilitate these duties' fulfillment. Ahistorical goods, and in particular many of the goods standardly thought to advance our welfare, do not lose their value when others are largely responsible for their realization. This is not to say that we lack reason to resent others' paternalistic efforts to help us realize ahistorical goods. ${ }^{5}$ Rather, historical goods, of which the fulfillment of self-regarding duties is an instance, are such that we have a distinctive reason to resent paternalistic efforts to assist us in their fulfillment, namely, that the relation between the subject and object of these duties is internal or constitutive, such that the extent that others are responsible for their fulfillment and the goods realized in their fulfillment stand in an inverse relation.

Let us briefly address a worry about how I have argued for the claim we have reasons to oppose paternalism aimed at inculcating self-regarding virtues and the fulfillment of duties to self. My arguments have leaned heavily on Kant's specific understanding of duties to self: that they are duties of virtue, requiring one adopt particular ends, not just perform certain acts or pursue certain outcomes; that because they are duties of virtue, duties to self are historical, requiring for their fulfillment our recognition of reasons to treat ourselves with respect; and that to the degree others are volitionally responsible for duties to self being "met," the duties become unmoored from the values that lend the duties their rationale. Of course, other conceptions of duties to self, including ones that see them not as duties of virtue but simply as requiring one to bring about particular outcomes, are possible. (A quasi-Kantian conception could require that we preserve our lives, for example, but not that we do so from the recognition that our lives and the rational agency they embody are worthy of respect.) But note that such conceptions render obscure why duties to self are incumbent specifically on oneself. For if the nature of the self demands that a particular outcome concerning the self be realized, why does the obligation to realize it fall on oneself rather than on others? At the very least, non-Kantian conceptions of duties to self, wherein they rest on ahistorical goods and are not duties of virtue, will struggle to explain why the duties in question are duties to self.

\section{Conclusion}

Duties to self are an underexplored topic in contemporary philosophy, and the implications of such duties even less explored. Here I have argued that we have distinct reasons to resent paternalism aimed at enabling us to fulfill our self-regarding duties. I am circumspect enough to recognize that my argument has merely opened the door to further discussion of these matters, but it appears at least to shift the burden onto those who would defend paternalism motivated by a concern that others fulfill their duties to self.

\section{Related topics}

Kantian Perspectives on Paternalism; Moralism and Moral Paternalism; Paternalism and Well-Being.

\section{Notes}

1 For a more thorough discussion of Kant's account, see Cholbi (2016: 54-60), as well as Jeske (1996) and Denis (2001).

2 These controversial claims include that lying and the pursuit of sexual gratification are violations of duties to self (see Cholbi 2016: 56-58, 175-182 for discussion), as well as what Timmermann (2006: 508-510) calls Kant's "primacy thesis," that duties to self provide the "foundation" or "preconditions" of all moral duty. 


\section{Michael Cholbi}

3 I take this to be a different matter than whether duties to self might be overridden by duties to others, a prospect that Kant took seriously (1996:177/6:423, 184/6:432).

4 And of course this does not preclude such measures being justified on nonpaternalistic grounds (e.g., that excessive drinking poses risks to those besides the drinker).

5 A still more complicated sort of case is when a given good has both a historical and an ahistorical value. Physical health presumably has ahistorical value, but its cultivation is also a Kantian duty to self resting on historical value. This presents a conflict between welfare paternalism and moral antipaternalism which I will not attempt to resolve here.

\section{References}

Anderson, E. (1993) Value in Ethics and Economics, Cambridge, MA: Harvard University Press.

Baier, K. (1958) The Moral Point of View, Ithaca: Cornell University Press.

Bradford, G. (2015) Achievement, Oxford: Oxford University Press.

Cholbi, M. (2011) Suicide: The Philosophical Dimensions, Peterborough, ON: Broadview.

- (2014) "Agents, Patients, and Obligatory Self-benefit," Journal of Moral Philosophy 11: 159-184.

. (2015) “On Marcus Singer's ‘On Duties to Oneself,” Ethics 125: 851-853.

- (2016) Understanding Kant's Ethics, Cambridge: Cambridge University Press.

Darwall, S. (2002) Welfare and Rational Care, Princeton, NJ: Princeton University Press.

Denis, L. (2001) Moral Self-regard: Duties to Oneself in Kant's Moral Theory, New York: Garland.

Finlay, S. (2008) "Too Much Morality?” in P. Bloomfield (ed.) Morality and Self-Interest, Oxford: Oxford University Press, pp. 136-154.

Hills, A. (2003) "Duties and Duties to Self," American Philosophical Quarterly 40: 131-142.

Jeske, D. (1996) "Perfection, Happiness, and Duties to Self," American Philosophical Quarterly 33: 263-276.

Kant, I. (1996) Metaphysics of Morals, trans. M. Gregor, Cambridge: Cambridge University Press (References include original Berlin Akademie, 1901 pagination).

May, S. C. (2015) “Directed Duties," Philosophy Compass 10: 523-532.

Mill, J. S. (1859) On Liberty, London: Parker \& Son.

Scanlon, T. M. (2008) Moral Dimensions: Meaning, Permissibility, and Blame, Cambridge, MA: Harvard University Press.

Singer, M. G. (1959) “On Duties to Oneself,” Ethics 69: 202-205.

Singer, P. (2011) The Expanding Circle: Ethics, Evolution, and Moral Progress, Princeton, NJ: Princeton University Press.

Timmermann, J. (2006) “Kantian Duties to the Self, Explained and Defended,” Philosophy 81: 505-530.

Velleman, J. D. (1999) “A Right of Self-Termination?” Ethics 109: 606-628. 